\title{
Information Usefulness in an Information System: Performance at the Strategic Level of the Organization
}

\author{
Sabrina ZAÏDI-CHTOUROU and Laïd BOUZIDI \\ Université Lyon, Centre de Recherche Magellan, IAE, Lyon, France
}

\begin{abstract}
This research studies the relation between information quality management in an information system and performance at the strategic level of the organization. This relation includes the "usefulness" which is an aspect of information quality management and organizational strategy's benefits. Through a quantitative analysis, this study demonstrates that attention to the improvement of information usefulness identified as a significant explanatory variable may improve organization benefits. Differentiation found among stakeholders in different roles was also examined in this study. Unexpected differences in the perception of the usefulness were, however, observed between stakeholders in the service sector, industry and other sectors. The data analysis allowed us to measure the relation between user perception of information usefulness in the marketing information system (MIS) and perception of the strategic benefits. Although this study is adapted to a marketing context and it applies essentially to marketing information used in production or servuction, the impact of the usefulness of this information is naturally situated at the strategic level of the company.
\end{abstract}

Keywords: information quality, information usefulness, information system, organizational outcomes

\section{Introduction}

During these last forty years there have been subtle changes in the theory and practice of the marketing in companies. These changes are also evident in marketing and management with the adoption and development of information systems. The relation between information and decision-making is a complex domain which has been at the center of research for several years. More recently, researchers have evidenced a relation between information quality and quality in decision-making which has consequences on the organizational strategy. The interest of this research lies in the explanation of the relation between the information quality management in a

Copyright (C) 2010 Sabrina ZAÏDI-CHTOUROU and Laïd BOUZIDI.This is an open access article distributed under the Creative Commons Attribution License unported 3.0, which permits unrestricted use, distribution, and reproduction in any medium, provided that original work is properly cited.

Contact Author: Sabrina ZAÏDI-CHTOUROU, e-mail: schtourou@univ-lyon3.fr 
MIS and performance at the strategic level of the organization.

This study asks several questions: Is there a relation between the improvement of information usefulness perceived by actors and organizational results?

What effects of interaction are there between the various aspects of improvement of information usefulness of the MIS and strategic organizational profits?

A model will be presented and it adduces empirical support for its validity. The research supplies empirical details of stakeholder perception of the relation between information quality and organizational benefits.

\section{Marketing information systems: "a strategic role"}

Marketing presents information which is an essential resource to attract the consumer, to confront the competition, to define marketing orientations (conception of product, location, etc.), to choose and spread messages suited to the multiple public of the organization and to estimate efficiency and relevance of implemented means. With the advent of information technologies, this information regrettably constitutes a very heterogeneous and ill-assorted dataset as answers to open questions, contents of conversations, company documents, promotional messages, etc. (GavardPerret, 1998). With the emergence of relational marketing and the personalization of the customer relationship, companies are sure to detain real goldmines thanks to their data warehouses and they are becoming aware of the usefulness of these data and so try to exploit them. In marketing, customer or competitor information is essential. It is thus necessary to establish a relation between information quality collected in the MIS and its effect at the organizational level; for example, "Customer relationship management" with inappropriate target audience the marketing campaigns, the rate of return of mailings, benchmarking, etc. Companies are increasingly confronted with the necessity of controlling a marketing environment that is growing all the time and changes quickly. Their data processing increases as their competitive location becomes more dynamic and volatile.

\section{Information usefulness: a dimension of the data quality}

In the last thirty years, researchers have investigated a multitude of ways to conceptualize data quality. For example, Gallagher (1974) considered factors such as usefulness, attraction, level of meaning, and relevance, among others, as determinants of the value of information systems. Halloran et al (1978) concentrated on accuracy, relevance, perfection, recovery, access security and opportunity. They indicated a measured scale for each of them in terms of a global system.

\section{A coherent model of data quality}

By the middle of the 1990s research on information quality began to form around a common framework. In particular, Wang et al (1995) proposed a framework derived from ISO 9000 to classify data quality research. They showed an analogy between the manufacture of products and data processing. Indeed, information systems are considered as similar to manufacturing systems. The data are then considered as raw materials and, when treated, when they are sometimes also called information, are considered as finished products. In this model, the storage of data is comparable to the storage of goods. Using the ISO 9000 concept "Description and Conception" 
Wang et al (1995) translate the necessity of indicating various aspects of data quality, such as criteria of acceptance and refusal, corresponding to management policy and subjected to management processes. Adopting a customer perspective similar to that recommended by Juran (1988), Wang et al (1995) noticed that the use of the term "data product" underlines the fact that the produced data have a value which is transferred to customers, that they are internal or external to the organization. This perspective was later famously adopted by Wang and Strong (1996) "to develop a framework that captures the aspects of data quality that are important to data consumers" (p. 5). They synthesized their results in the following way: the intrinsic data quality indicates that the data have the quality which is appropriate for them. The contextual quality stresses the condition according to which the data must be considered in the context of a precise task. The representative data quality and the accessible data quality underline the importance of the role of the systems. The authors summarize the consequences of their study in the following way: "These findings are consistent with our understanding that high-quality data should be intrinsically good, contextually appropriate for the task, clearly represented, and accessible to the data consumer" (p. 22). Figure 1 describes Wang and Strong's (1996) model of data quality as a multidimensional concept.

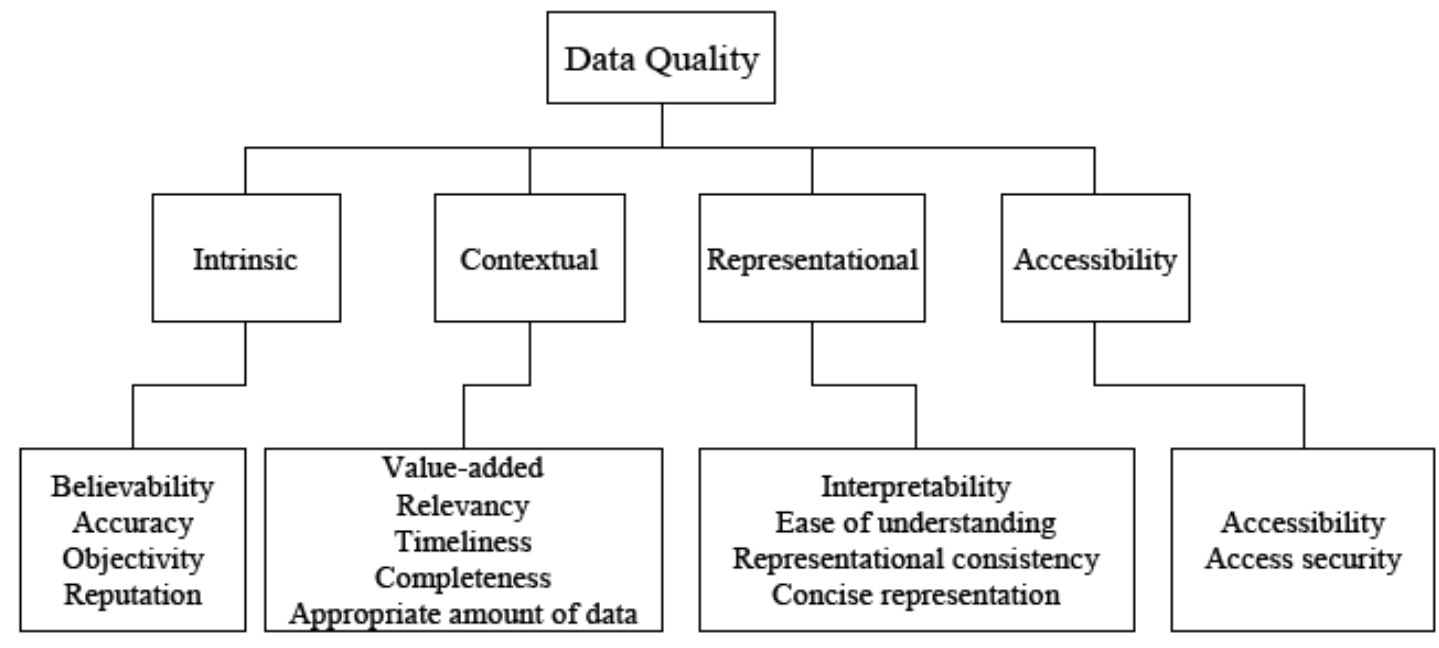

Fig. 1. Data quality as a multidimensional construct

\section{A model of the performance of products and services for information quality}

Kahn et al (2002) recognized that the dominant abstract models treated information as a product; nevertheless they noted that it "can also be conceptualized as a service" (p. 186). A service, unlike a product, "is perishable, for you cannot keep it; it is produced and consumed simultaneously" (p. 186).
Besides identifying the aspects of service of information quality, Kahn et al (2002) used general quality literature to identify other ways to characterize it: two of which they adopted for their purposes: "conformance to specifications" (p. 185) and "meeting or exceeding customer expectations" (p. 185). By combining these two definitions with both aspects (product and service) of information quality, Kahn et al (2002) developed a significant extension of Wang and 
Strong's (1996) model, entitled "Product and service performance model for quality information (PSP/IQ)." The PSP/IQ model is represented by a board with two lines and two columns (Table 1).

The quality of products and services are presented in lines and the specifications with regard to expectations are presented in columns. The various dimensions of the quality information model developed by Wang and Strong (1996) are schematized by two lines and two columns. Each of the quadrants has been assigned a short, descriptive name. On the product side, the product-conformance quadrant is referred to as "sound information" (Kahn et al, 2002, p. 189) and the productexpectations quadrant represents "useful information" (p. 189). On the service side, the service-conformance quadrant represents "dependable information" ( $p$. 189), with "usable information" (p. 189) making up the service expectation quadrant.

The dimensions in italics in the "Usefulness" quadrant were registered marginally in the cell.

Table 1: The PSP/IQ model Kahn et al (2002)

\begin{tabular}{|c|c|c|}
\hline & $\begin{array}{l}\text { Conforms to } \\
\text { Specifications }\end{array}$ & $\begin{array}{l}\text { Meets or Exceeds } \\
\text { Expectations }\end{array}$ \\
\hline Product & $\begin{array}{l}\text { Soundness } \\
\text { • Free of error } \\
\text { - Concise representation } \\
\text { - Completeness } \\
\text { - Consistent representation }\end{array}$ & $\begin{array}{l}\text { Usefulness } \\
\text { - Appropriate amount } \\
\text { - Relevancy } \\
\text { - Understandability } \\
\text { - Interpretability } \\
\text { - Objectivity }\end{array}$ \\
\hline Service & $\begin{array}{l}\text { Dependability } \\
\text { - Timeliness } \\
\text { - Security }\end{array}$ & $\begin{array}{l}\text { Usability } \\
\text { • Believability } \\
\text { - Accessibility } \\
\text { - Ease of operation } \\
\text { - Reputation } \\
\text { - Value-added }\end{array}$ \\
\hline
\end{tabular}

Mirani and Lederer (1998) developed a tool to measure a set of organizational benefits in each of the categories illustrated in Figure 1 by using using two to four survey items per category. A narrower observation of the items which measure the informative advantages indicates that every item reflects one or more of the dimensions identified by the factorial analysis of Wang and Strong (1996). Lee et al (2002) developed a useful methodology to identify aspects of information quality which require particular attention. Their methodology is developed from PSP/IQ to establish benchmarks. It includes two forms of gap analysis. The first one is called "Benchmarking Gap Analysis." Table 2 recapitulates the results of this study: the column on the left-hand side shows the informative categories of advantages and links the items described by Mirani and Lederer (1998). The central column shows the dimensions proposed by Wang and Strong (1996) and the facts that correspond with the category "information quality." Finally, the righthand column presents the reserved level of Lee et al (2002). 
Table 2: Comparison of the informative advantages of Mirani and Lederer (1998), dimensions of Wang and Strong (1996) and levels of the model PSP/IQ of Lee et al (2002)

\begin{tabular}{|l|c|c|}
\hline $\begin{array}{l}\text { Mirani and Lederer } \\
(1998)\end{array}$ & Wang and Strong (1996) & Lee et al. (2002) \\
\hline $\begin{array}{l}\text { Info. Quality: Improve } \\
\text { information for } \\
\text { operational control }\end{array}$ & Relevancy (Contextual) & Usefulness \\
\hline
\end{tabular}

\section{Methodological approach}

This research describes contextual and conceptual models moving marketing quality information closer to marketing strategy and proposes an empirical study on the relation between the usefulness of information marketing and strategic organizational advantages. The model (Figure 2) identifies a specific aspect of information quality: "the usefulness" and a category of organizational results which represents strategic advantage. Each of these items constitutes a variable in the abstract model.

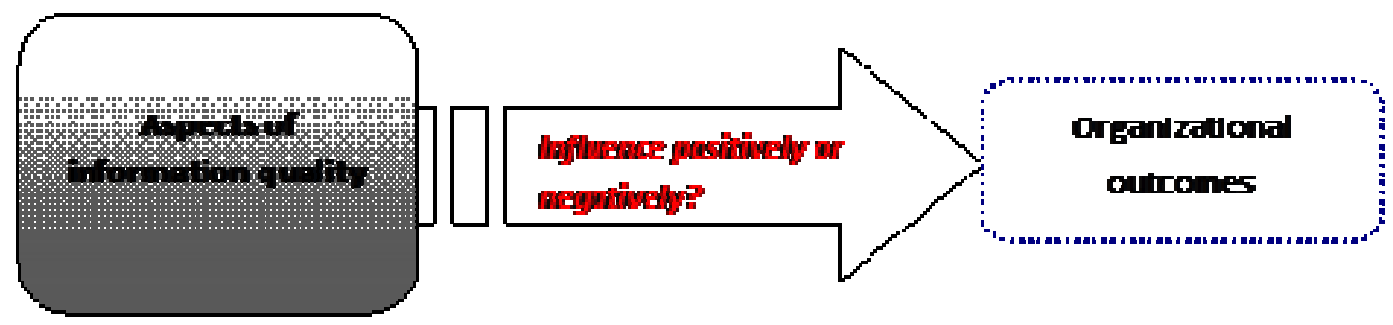

Fig. 2. Strategic relation between aspects of information quality and organizational benefits

These variables were used to measure user perceptions and the decision-makers of the MIS in terms of importance, current state, and organizational benefits derived from the information usefulness of their organization. Analysis allowed us to measure the relation between user perception of information quality at the level of the MIS and perceptions of the strategic advantages. Strategic advantages include competitive advantage, alignment between the business and information systems, and customer relations improvement (Mirani \& Lederer, 1998). We hypothesized that the improvement in diverse aspects of information quality would positively affect the strategic advantages. This hypothesis is summarized below:
H: Improvements in information usefulness will be associated / bound with greater strategic advantages.

\section{Measuring instrument and data analyses}

\section{Operationalizing the variables}

Two types of variables were operationalized for this study: independent variables measuring diverse aspects of information usefulness, dependent variables measuring the strategic organizational advantages at levels of marketing and the whole organization. A set of variables of identity 
was also included to facilitate the grouping of the answers.

The independent variables for this study were the ones employed to measure information quality. These variables were operationalized on two levels: the level dimension and the level PSP/IQ. The level dimension was directly measured by using 20 items of the instrument of evaluation of information quality (IQA) developed by Lee et al (2002); this is presented in Appendix 1. This instrument uses a scale from 1 to 10 , where $1=$ "in no way" and 10 = "totally"; no median point was proposed. An independent variable represented by information usefulness was calculated as the mean value of the response items measuring that particular dimension.

The items which are followed by $₫$ are also proposed but inverted.

The dependent variables for this study correspond to those used to measure strategic organizational advantages. The level "Strategic advantages" was directly measured by employing eleven relevant items of the "Organizational Benefits of IS Projects instrument" developed by Mirani and Lederer (1998) and are presented in Appendix 2. This instrument uses a scale from 1 to 7 , where 1 = "no advantage" and $7=$ "a very important advantage." The median point is not identified for this scale. The dependent variable "Strategic organizational advantages" is calculated as the mean value of the response items measuring this dimension. Questions of identity were included and supply us with a basal identification of the participants; they are necessary to study data models and to identify possible sources of error.

Question filters were used to classify people picked to participate in this study. The requirements were that they had to work for a company or an organization and those they interacted regularly with information on products or services (for example, through an application, a database, or an information report). Such an interaction can be bound to that to supply or collect information, to run or to watch the preservation of information or to consume/use information on products and services. To obtain a more useful study, before seeking the referees, we chose persons according to their attributes. The survey includes questions about the qualifications required at the end.

The questions about classification were included in this survey to identify participant functions, as well as provide information on the participant's organization, including the business sector and the size of the company.

\section{Data processing}

The collection and the data analysis adduced empirical proof of the validity of the proposed model. The data for this study were gathered by means of a webbased survey and the participants were associated with the function Marketing. All in all, 552 individuals were invited to participate in a web-based survey and 107 answers were received. The data were prepared, verified, and examined for wrong observations and missing values. They were assessed by a combination of multiple and moderate multiple regression analysis. The data analysis showed that the relation between marketing quality information and organizational advantages is measurable methodologically. These measures of information quality can be used to plan performance at the marketing level on the strategic level. The analysis showed that the relation was generally positive. An unexpected discovery was that different models in the regression appear when the business sectors and the roles of the user in a MIS are considered. These analyses allowed us to validate the main hypothesis, as well as several secondary 
hypotheses which were developed to verify the systematic differences discovered during examination of the data. Univariate analysis was conducted on all the variables to insure proper coding and proper recording of all values. On the basis of this analysis, we determined that seven cases must be removed. The sample therefore returned 100 useful cases for analysis and the missing data among these cases did not cause a systematic problem.

To determine if there were significant differences in the answers according to the various business sectors, a one-way ANOVA was performed. Items turned out to present significant differences $(\mathrm{p}=$ 0.01). A more meticulous study indicated a systematic model in which participants from the "Other business sectors" estimated information quality in their systems higher than those belonging to a service company who in turn estimated the quality higher than those belonging to an industrial company. This model indicated that a separate analysis was necessary to estimate the implications of these differences.

We also determined the convergent and discriminant validity of the measuring instrument. Cronbach alpha was calculated for each set of items "Strategic advantages" and "usefulness of information" of the study. These values are enumerated in Tables 3 and 4 . Examination of those dimensions with alphas below 0.7 indicated that no adjustments could be made to improve the alpha concerning Alignment, Objectivity and Understandability. Consequently these items were removed.

Table 3. Organizational Benefits Item Convergence

\begin{tabular}{llcc} 
Category & Dimension & Number of items & a Cronbach \\
Strategic benefits & $\underline{\text { Alignment }}$ & 4 & 0.67 \\
Strategic benefits & $\underline{\text { Competitive advantage }}$ & 3 & 0.77 \\
Strategic benefits & Customer relations & 4 & 0.86 \\
& & & \\
\hline
\end{tabular}


Table 4. Information Usefulness Item Convergence

\begin{tabular}{|c|c|c|}
\hline $\begin{array}{l}\text { PSP/IQ Quadrant } \\
\boldsymbol{\alpha} \text { Cronbach }\end{array}$ & Dimension & items \\
\hline $\begin{array}{r}\text { Usefulness } \\
0.77\end{array}$ & Appropriate Amount & 4 \\
\hline $\begin{array}{r}\text { Usefulness } \\
0.77\end{array}$ & Interpretability & 4 \\
\hline $\begin{array}{l}\text { Usefulness } \\
0.61\end{array}$ & Objectivity & 2 \\
\hline $\begin{array}{r}\text { Usefulness } \\
0.80\end{array}$ & Relevancy & 3 \\
\hline $\begin{array}{l}\text { Usefulness } \\
0.56\end{array}$ & $\underline{\text { Understandability }}$ & 2 \\
\hline
\end{tabular}

Having looked for possible outliers, we addressed systematic differences among the participants according to business

\section{Results}

\section{Test of hypothesis}

H: Improvements in information usefulness will be associated / bound with greater strategic advantages.

The independent variables associated with this hypothesis are Quantity, Interpretation, and Relevance. The dependent variable, Strategic advantages, represents the average statistics of variables Competitive advantage and Customer relationship. Among these variables, only one presents significant differences between the various business sectors. To show these differences, the following three sub-hypotheses were also estimated: sector by performing one-way ANOVA on the constructed variables. Significant differences of $p=0.05$ were found for the variable "Customer relationship."
Ha: Improvements in information usefulness will be associated with greater strategic advantages measured in service activities.

Hb: Improvements in information usefulness will be associated with greater strategic advantages measured by industrial activities. 
Hc: Improvements in information usefulness will be associated with greater strategic advantages measured in other activities.

To estimate $\mathrm{H}$, stepwise multiple regression analysis was conducted to determine which of the independent variables (Quantity, Interpretation and Relevance) explained the variable Strategic advantages. The descriptive statistics for these variables, a summary of the model of regression and The bivariate and partial correlation coefficients between the predictor and the dependent variable are shown in Appendix 3. The results of the regression indicate a general model with an explanatory variable (Relevance) which significantly explains way the strategic advantages; R2 $=0.148$, R2 adjustment = $0.139, \mathrm{~F}(1.96)=16.624, \mathrm{p}<0.001$. This model, for which we observe a tolerance of 1.00 , explains $14 \%$ of the variance of Strategic advantages. The analysis of residues indicated no evident violation of the acceptances of linearity, normality, or homoskedasticity, and hence the results of this multiple regression analysis are accepted as tenable and the null hypothesis Hnull is rejected.

To estimate $\mathrm{Ha}, \mathrm{Hb}$ and $\mathrm{Hc}$, stepwise multiple regression analysis was conducted to determine which of the independent variables (Quantity, Interpretation and Relevance) explained the strategic advantages measured respectively in service, industrial and other activities. The descriptive statistics for these variables, a summary of the models of regression and the coefficients of correlation for two variables and the bivariate and partial correlation coefficients between the predictor and the dependent variable are presented in Appendix 4.

Regression results indicate an overall model with one predictor variable for each of the sectors. The variable Relevance significantly explains the strategic advantages in service activities, as well as in the industrial sector. The variable Interpretation significantly explains the strategic advantages in the other sectors.

\section{Summary of hypothesis testing}

The analysis above allows us to support the main hypothesis, as well as three additional sub-hypotheses proposed to estimate differences resulting from disparities in the business sectors. Table 5 supplies the relevant summary. Table 6 supplies a summary of the explanatory variables and their significant relations.

Table 5: Summary of Support for Main Effect Hypotheses

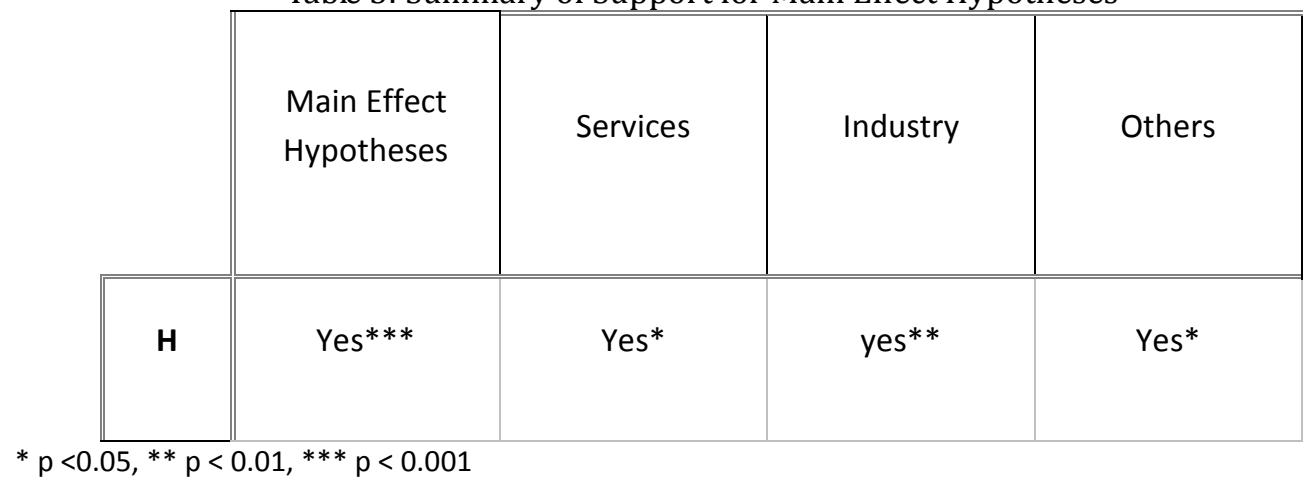


Table 6: Summary of Predictor Variables

\section{$\begin{array}{lll}\text { Predictor variable } & \text { Criterion variable } & \text { Hypotheses }(\boldsymbol{\beta})\end{array}$}

\section{Usefulness}

$\begin{array}{lll}\text { Appropriate Amount } & \text { None } & \\ \text { Interpretability } & \text { Strategic benefits } & \mathrm{Hc}(0.68) \\ \text { Relevance } & \text { Strategic benefits } & \mathrm{H}(0.38), \mathrm{Ha}(0.28), \\ & \mathrm{Hb}(0.55)\end{array}$

\section{Discussion}

This study investigated the relationship between the management of information usefulness contained in MIS and strategic organizational advantages.

Certain items of the instrument questioned the participants about the business sectors of the company. The considered sectors were services, industry and other sectors. We had not expected that the business sector could significantly influence performance appraisal strategy. The analysis of collected data effectively indicated that this effect was very evident in the sample. To explain the differences, every affected hypothesis was estimated by four different methods. First, the original hypothesis was estimated by using all the data to produce a general predictive model. It was estimated a further three times to test the sub-hypotheses, by using only the data representing predictive models for every business sector. As we have already emphasized, the differences in the perception of the impact of information usefulness on organizational advantages for the business sector were unexpected. Some of these analyses were, however, the result of completely different predictive models, according to the business sector.

The hypotheses for this study took into account information quality by using PSP/IQ model bases developed by Kahn et al (2002) and Lee et al (2002). The studied hypothesis considered a cell of the model PSP/IQ by using the various dimensions bound to this cell as independent variables. The predictive models are slightly less complex than planned. We found models of simple linear regression with only a single explanatory variable for each of them. We propose to use the obtained results for a synthesis explaining user perception of information usefulness and its impact on organizational level in a MIS.

We admit that improvement of information quality improves management decisions. We know that the difficulty for organizations wishing to set up a strategy of information quality, the main objective of which is naturally its improvement, lies in the perception which the actors have of this improvement on the results at their level or at a more general level of the organization. With the support of our 
results we can supply an inventory of fixtures of the "Usefulness" of the quality which seems more or less important according to the business sector. All the business sectors estimate that information usefulness have a positive impact on the organization results. But there are differences according to the types of got advantages. Strategic advantages include competitive advantage, adaptation by the activity and information systems and the improvement of the customer relationship. Our results show that the actors in the service sector perceive an influence of information quality on strategic advantages. This is explained by the interest which service companies have in the customer relationship.

Concerning the other sectors, certain dimensions are positively estimated at the level of strategic advantages. We summarize the results in Figure 3. This figure shows the usefulness dimensions in which improvement will have a positive impact on the organization outcomes according to the type of sector. We consider information as an informative product for which we measure the quality (Usefulness). 


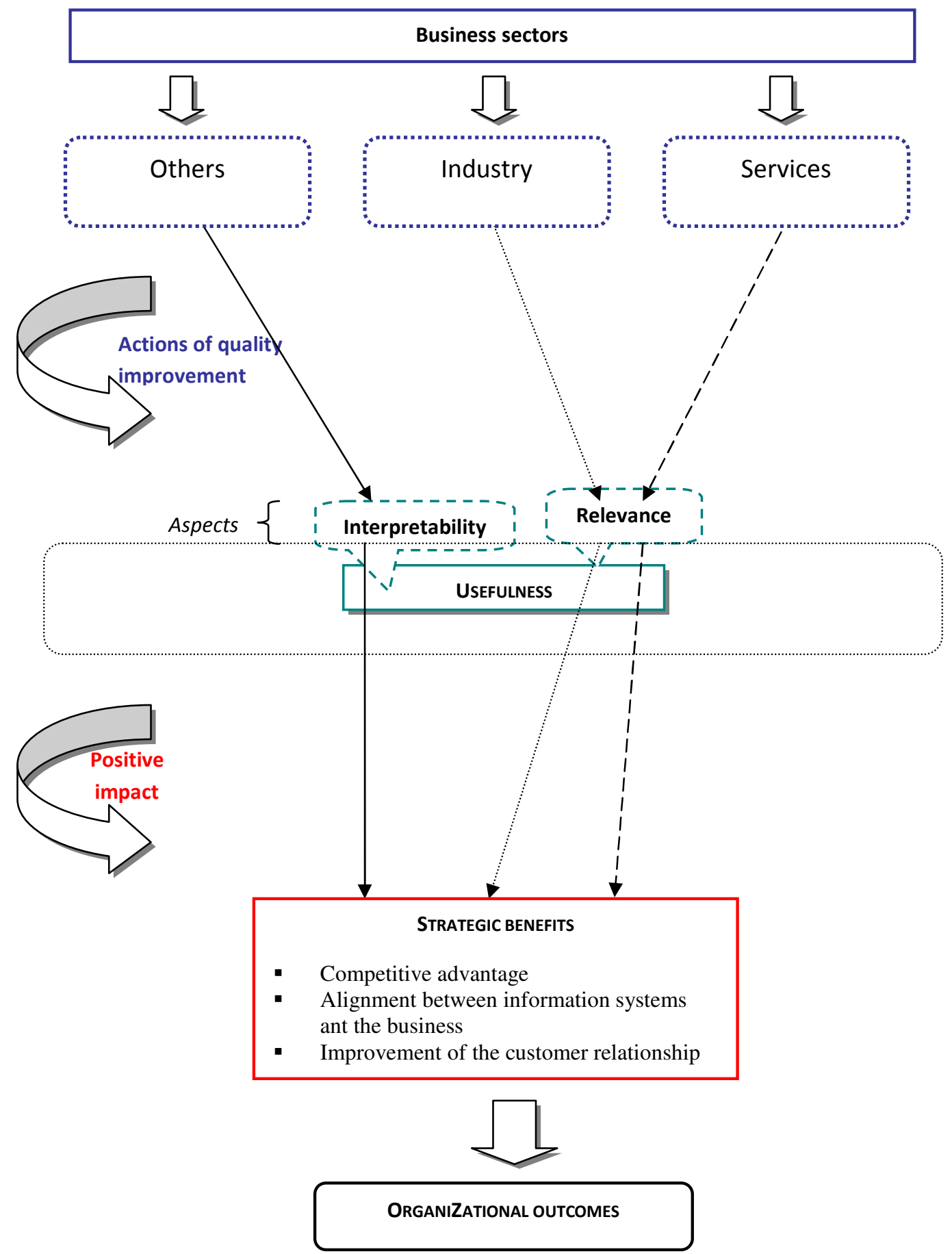

Fig. 3. Synthesis of the perception of information usefulness of the strategic organizational advantages according to the business sector 


\section{Conclusion}

The study allowed us to investigate the relation between the management of quality in terms of usefulness of information contained in the MIS and the organizational outcomes at the strategic level. Analysis showed that the relation was generally positive. Data analysis measured the relation between user perception on information usefulness at the level of the MIS and perception of the strategic advantages by these same users.

An additional finding of this research is the discovery that the various business sectors consider not only information usefulness differently, but also in certain cases look at the advantages of this information differently. Future research should consider the business sector of organizations, which, as it provides a service or makes a product, does not consider the advantages of information quality in the same way as other sectors.

\section{References}

Gallagher, C.A. (1974) Perceptions of the value of a management information system. Academy of Management Journal, 17 (1), 46-55.

Gavard-Perret, M.L. (1998) De l'énoncé à l'énonciation: pour une relecture de l'analyse lexicale en marketing. Recherche et Applications en Marketing, 13 (2), 3147.

Halloran, D., Manchester, S., Moriarty, J., Riley, R., Rohrman, J. \& Skramstad, T. (1978) Systems development quality control. MIS Quarterly, 2 (4), 1-13.

Juran, J.M. (1988) Juran on planning for quality. New York, The Free Press.
Kahn, B.K., Strong, D.M. \& Wang, R.Y. (2002) Information quality benchmarks: Product and service performance. Communications of the ACM, 45 (4), 184192.

Lee, Y.W., Strong, D.M., Kahn, B.K. \& Wang, R.Y. (2002) AIMQ: A methodology for information quality assessment. Information and Management, 40 (2), 133-146.

Mirani, R. \& Lederer, A.L. (1998) An instrument for assessing the organizational benefits of IS projects. Decision Sciences, 29 (4), 803-838.

Wang, R.Y., Storey, V.C. \& Firth, C.P. (1995) A framework for analysis of data quality research. IEEE Transactions on Knowledge and Data Engineering, 7 (4) 623-640.

Wang, R.Y. \& Strong, D.M. (1996) Beyond accuracy: What data quality means to data consumers. Journal of Management Information Systems, 12 (4), 5-34.

\section{Appendix 1: Information Usefulness Measurement Items}

\section{Quantité Suffisante ou Appropriée}

- Ces informations sont disponibles en quantité suffisante pour nos besoins. QIUQ1

- La quantité d'informations ne correspond pas à nos besoins. ${ }^{\circledR}$ QIUQ2

- La quantité d'informations n'est pas suffisante pour nos besoins. ® QIUQ3

- La quantité d'informations n'est ni trop importante ni trop faible. QIUQ4 
Interprétation

- Il est facile d'interpréter ce que ces informations signifient. QIUIP1

- Ces informations sont difficiles à interpréter. ® QIUIP2

- Il est difficile d'interpréter les informations codées/chiffrées. ® QIUIP3

- Ces informations sont facilement interprétables. QIUIP4

- Les unités de mesure pour ces informations sont claires. QIUIP5

\section{Objectivité}

- Ces informations ont été collectées avec objectivité. QIUO1

- Ces informations reposent sur des faits. QIUO2

- Ces informations sont objectives. QIUO3

- Ces informations présentent une vision impartiale et neutre. QIU04
Pertinence

- Ces informations sont utiles pour notre travail. QIUP1

- Ces informations sont pertinentes pour notre travail. QIUP2

- Ces informations sont appropriées à notre travail. QIUP3

- Ces informations sont applicables à notre travail. QIUP4

Intelligibilité / Compréhension

- Ces informations sont faciles à comprendre. QIUIL1

- La signification de ces informations est difficile à comprendre. $®$ QIUIL2

- La signification de ces informations est facile à comprendre. QIUIL3 
Appendix 2: Organizational Benefits Measurement Items

Catégorie/Dimension «L'utilisation des informations dans ce SIM... »

AVANTAGES STRATÉGIQUES

Avantage concurrentiel

Alignement

Relation client
Augmente la compétitivité et crée un avantage stratégique. (ASAC1)

Permet à l'organisation d'être plus compétitive. (ASAC2)

Permet de prendre des décisions à long terme (marketing stratégique). (ASAC3)

Est en adéquation avec les objectifs stratégiques de l'entreprise. (ASA1)

Favorise les relations avec d'autres organisations. (ASA2)

Permet à l'organisation de répondre plus rapidement au changement. (ASA3)

Permet de prendre des décisions à court terme (marketing opérationnel). (ASA4)

Améliore la relation avec les clients. (ASRC1)

Permet d'offrir de nouveaux produits ou services aux clients. (ASRC2)

Permet de fournir de meilleurs produits ou services à nos clients. (ASRC3)

Permet de fidéliser les clients. (ASRC4)

Appendix 3: Descriptive Statistics, Summary of the model and coefficients for $H$ 
Statistiques descriptives

\begin{tabular}{|l|r|r|r|}
\hline & \multicolumn{1}{|c|}{ Moyenne } & Ecart-type & \multicolumn{1}{|c|}{ N } \\
\hline AVANTAGES & 4,9188 & 1,33143 & 98 \\
STRATEGIQUES & & & \\
Quantité & 6,6352 & 1,74176 & 98 \\
Interprétation & 6,4320 & 1,71687 & 98 \\
Pertinence & 7,6122 & 1,60946 & 98 \\
\hline
\end{tabular}

Récapitulatif du modèle

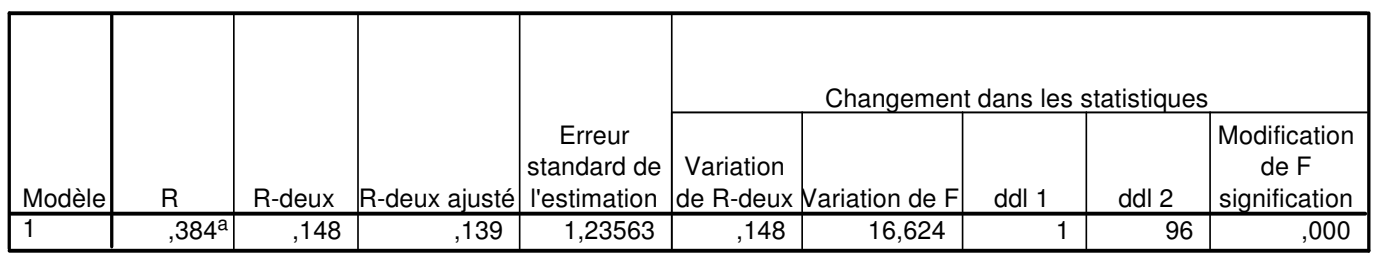

a. Valeurs prédites : (constantes), Pertinence

b. Variable dépendante : AVANTAGES STRATEGIQUES

Coefficients

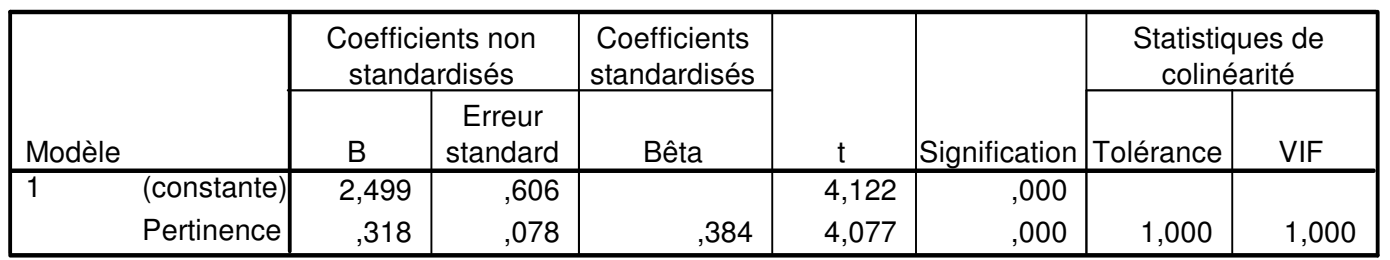

a. Variable dépendante : AVANTAGES STRATEGIQUES 
Appendix 4: Descriptive Statistics, Summary of the model and coefficients for $\mathrm{Ha}, \mathrm{Hb}$ and Hc

\section{Ha: Activités de services}

Statistiques descriptives

\begin{tabular}{|l|r|r|r|}
\hline & \multicolumn{1}{|c|}{ Moyenne } & Ecart-type & \multicolumn{1}{|c|}{ N } \\
\hline AVANTAGES & 4,8485 & 1,32958 & 63 \\
STRATEGIQUES & & & \\
Quantité & 6,6667 & 1,71274 & 63 \\
Interprétation & 6,6521 & 1,75048 & 63 \\
Pertinence & 7,7725 & 1,45522 & 63 \\
\hline
\end{tabular}

Récapitulatif du modèłe

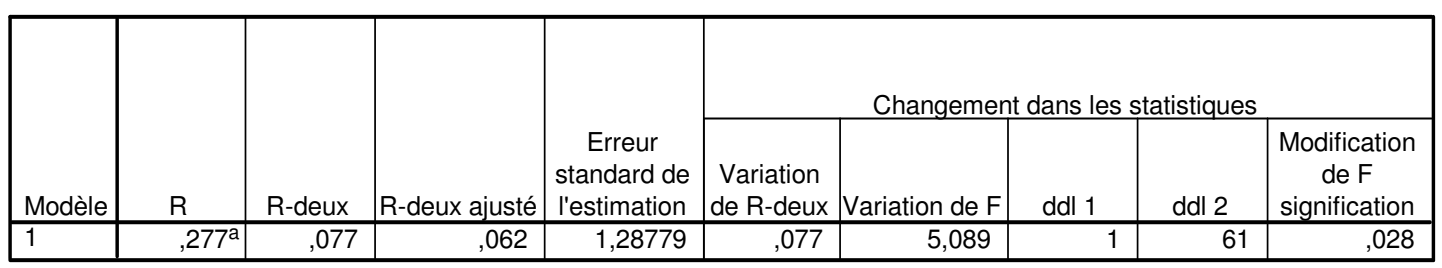

a. Valeurs prédites : (constantes), Pertinence

b. Variable dépendante : AVANTAGES STRATEGIQUES

Coefficients

\begin{tabular}{|c|c|c|c|c|c|c|c|c|}
\hline \multirow{2}{*}{\multicolumn{2}{|c|}{ Modèle }} & \multicolumn{2}{|c|}{$\begin{array}{l}\text { Coefficients non } \\
\text { standardisés }\end{array}$} & \multirow{2}{*}{$\begin{array}{c}\text { Coefficients } \\
\text { standardisés } \\
\text { Bêta }\end{array}$} & \multirow[b]{2}{*}{$t$} & \multirow[b]{2}{*}{ Signification } & \multicolumn{2}{|c|}{$\begin{array}{c}\text { Statistiques de } \\
\text { colinéarité }\end{array}$} \\
\hline & & B & $\begin{array}{l}\text { Erreur } \\
\text { standard }\end{array}$ & & & & Tolérance & VIF \\
\hline & (constante) & 2,878 &, 888 & & 3,239 & ,002 & & \\
\hline & Pertinence & ,254 & ,112 & ,277 & 2,256 & ,028 & 1,000 & 1,000 \\
\hline
\end{tabular}

a. Variable dépendante : AVANTAGES STRATEGIQUES

\section{$\underline{\text { Hb}: \text { Activités industrielles }}$}

Statistiques descriptives
\begin{tabular}{|l|r|r|r|}
\hline & \multicolumn{1}{|c|}{ Moyenne } & \multicolumn{1}{|c|}{ Ecart-type } & \multicolumn{1}{c|}{ } \\
\hline AVANTAGES & 4,6775 & 1,49437 & 23 \\
STRATEGIQUES & 6,5435 & 1,72984 & 23 \\
Quantité & 5,9130 & 1,62650 & 23 \\
Interprétation & 6,9275 & 2,03742 & 23 \\
Pertinence &
\end{tabular}


Récapitulatif du modèle

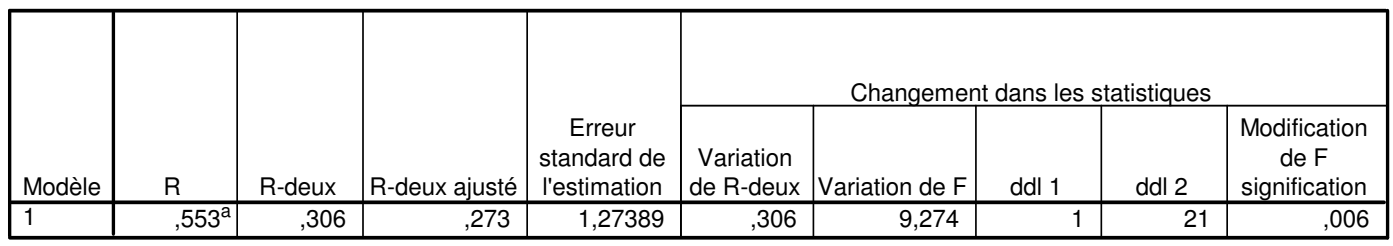

a. Valeurs prédites : (constantes), Pertinence

b. Variable dépendante : AVANTAGES STRATEGIQUES

Coefficients

\begin{tabular}{|c|c|c|c|c|c|c|c|c|}
\hline \multirow[b]{2}{*}{ Modèle } & & \multicolumn{2}{|c|}{$\begin{array}{l}\text { Coefficients non } \\
\text { standardisés }\end{array}$} & \multirow{2}{*}{$\begin{array}{c}\text { Coefficients } \\
\text { standardisés } \\
\text { Bêta }\end{array}$} & \multirow[b]{2}{*}{$t$} & \multirow[b]{2}{*}{ Signification } & \multicolumn{2}{|c|}{$\begin{array}{l}\text { Statistiques de } \\
\text { colinéarité }\end{array}$} \\
\hline & & B & $\begin{array}{c}\text { Erreur } \\
\text { standard }\end{array}$ & & & & Tolérance & VIF \\
\hline & (constante) & 1,865 &, 961 & & 1,941 & ,066 & & \\
\hline & Pertinence & ,406 & ,133 & ,553 & 3,045 & ,006 & 1,000 & 1,000 \\
\hline
\end{tabular}

a. Variable dépendante : AVANTAGES STRATEGIQUES

\section{Hc: Activités activités}

Statistiques descriptives

\begin{tabular}{|l|r|r|r|}
\hline & \multicolumn{1}{|c|}{ Moyenne } & Ecart-type & \multicolumn{1}{|c|}{$\mathrm{N}$} \\
\hline AVANTAGES & 5,7500 &, 54616 & 12 \\
STRATEGIQUES & & & 12 \\
Quantité & 6,6458 & 2,05177 & 12 \\
Interprétation & 6,2708 & 1,60063 & 12 \\
Pertinence & 8,0833 & 1,11124 & 12 \\
\hline
\end{tabular}

Récapitulatif du modèle

\begin{tabular}{|c|c|c|c|c|c|c|c|c|c|}
\hline \multirow[b]{2}{*}{ Modèle } & \multirow[b]{2}{*}{$\mathrm{R}$} & \multirow[b]{2}{*}{ R-deux } & \multirow[b]{2}{*}{ R-deux ajusté } & \multirow[b]{2}{*}{$\begin{array}{c}\text { Erreur } \\
\text { standard de } \\
\text { l'estimation }\end{array}$} & \multicolumn{5}{|c|}{ Changement dans les statistiques } \\
\hline & & & & & $\begin{array}{l}\text { Variation } \\
\text { de R-deux }\end{array}$ & Variation de $\mathrm{F}$ & ddl 1 & ddl 2 & $\begin{array}{l}\text { Modification } \\
\text { de F } \\
\text { signification }\end{array}$ \\
\hline 1 & ,679a & ,461 & ,407 & ,42043 &, 461 & 8,563 & 1 & 10 &, 015 \\
\hline
\end{tabular}

a. Valeurs prédites : (constantes), Interprétation

b. Variable dépendante : AVANTAGES STRATEGIQUES 


\begin{tabular}{|c|c|c|c|c|c|c|c|c|}
\hline \multicolumn{9}{|c|}{ Coefficients } \\
\hline \multirow[b]{2}{*}{ Modèle } & & \multicolumn{2}{|c|}{$\begin{array}{l}\text { Coefficients non } \\
\text { standardisés }\end{array}$} & \multirow{2}{*}{$\begin{array}{c}\text { Coefficients } \\
\text { standardisés } \\
\text { Bêta }\end{array}$} & \multirow[b]{2}{*}{$\mathrm{t}$} & \multirow[b]{2}{*}{ Signification } & \multicolumn{2}{|c|}{$\begin{array}{l}\text { Statistiques de } \\
\text { colinéarité }\end{array}$} \\
\hline & & B & $\begin{array}{l}\text { Erreur } \\
\text { standard }\end{array}$ & & & & Tolérance & VIF \\
\hline 1 & (constante) & 4,297 &, 511 & & 8,404 &, 000 & & \\
\hline & Interprétation & 232 & ,079 & 679 & 2,926 & ,015 & 1,000 & 1,000 \\
\hline
\end{tabular}

a. Variable dépendante : AVANTAGES STRATEGIQUES 